Session 2653

\title{
Academic Skills Seminar: A Two-Year Analysis of an Intrusive Intervention for Freshmen on Probation
}

\author{
Dr. Joanne Ingham, Dr. William R. McShane \\ Polytechnic University
}

\begin{abstract}
Approximately $25 \%$ of the freshman class at a small, private, engineering university were placed on academic probation each year. Students remaining on probation for more than one semester often were disqualified or withdrawn. Tinto (1993) reported that many students leave college as a result of unclear individual goals or intentions, a lack of connectedness with the institution or academic underachievement. Tinto (1993) further suggested that by identifying the problems students encounter and offering appropriate interventions, a resulting increase in persistence might result.
\end{abstract}

Several interventions with students on probation have been described with varied course content including study skills, time management, goal setting, and career orientation (Lipsky \& Ender, 1990; Carver \& Smart, 1985; Newton, 1990). Few programs were mandatory for second-semester freshmen placed on probation. Some programs were based upon differing theoretical frameworks (Coleman \& Freedman, 1996; Simmons, Wallins, \& George, 1995). Studies have also been conducted exploring student self-efficacy and academic success (Astin, 1993; Hackett, Casas, Betz \& Rocha-Singh, 1992; Wilhite, 1990; House, 1993; Quilter, 1995). Brown, Lent, and Larkin (1989) documented the interactions between aptitude and self-efficacy. Results indicated that strong academic self-concept was particularly important to the success of moderate-ability students and were also predictive of persistence and good grades in the sciences and engineering.

Marsh (1984a, 1984b; Marsh \& Parker, 1984) proposed a frame of reference model called the Big Fish, Little Pond (BFLP) effect. It was hypothesized that self-concept may be impacted 
by the context within which students find themselves. The BFLP effect occurs when equally able students have lower academic self-concepts when they compare themselves to more able students, and higher academic self-concepts when they compare themselves with less-able students (Marsh \& Craven, 1997). The resultant decrease in academic self-concept when students attend a more academically demanding school resulted in lower academic self-concept and lower GPAs (Marsh, 1991).

According to Marsh and Craven, (1997) appropriate interventions for students affected by the BFLP effect include providing frequent and timely feedback on long-term overall performance standards rather than focusing on comparison to peer performance, assisting students in identifying strengths and unique accomplishments and providing opportunities for group support with others experiencing academic difficulty. In addition, it was recommended that opportunities be provided within programs that complement the individual's preferred learning styles (Marsh \& Craven, 1997).

A number of researchers have examined metacognitive approaches using awareness of individual student learning styles as the focus for increasing levels of academic achievement, retention and academic self-concept (Lenehan, Dunn, Ingham, Signer \& Murray, 1994; Nelson, Dunn, Griggs, Primavera, Fitzpatrick \& Miller, 1993; Clay,1984). Previous experimental research with learning styles has been conducted in the content areas of math (Bruno, 1988), marketing (Dunn, Deckinger, Withers \& Katzenstein, 1990), education and nursing (Buell \& Buell, 1987), study skills (Napolitano, 1986) and anatomy (Cook, 1989). Results of these studies revealed that when students were made aware of their learning style preferences were taught new and difficult information in ways which complemented their individual learning style strengths, gains in academic achievement resulted.

In December, 1993, the University Retention Team proposed the creation of an Academic Skills Seminar designed to help improve retention. Statistics collected over a five- 
year period indicated that students who achieved less than a 2.0 cumulative grade point average for more than one semester were at-risk for withdrawing or disqualification. The persistence rates of 84 first-year students placed on academic probation in Spring , 1993 were tracked for a two-year period. After two years, 4 students (4.7\%) remained in good standing, $16(19.0 \%)$ continued on probation, $12(26.1 \%)$ were disqualified, and $50(59.4 \%)$ withdrew from school. To address this concern, the Academic Skills Seminar was proposed.

The Seminar was approved by the faculty in October, 1994 as a non-credit, eight week, one hour per week course open to all first-time probationary students and required of all first year, first-time probationary students. The Academic Skills Seminar was taught as a formal course for the first time during the Spring 1995 semester. All sections of the Seminar were taught by the Associate Dean of Undergraduate Studies and were evaluated on a pass/fail basis.

The curriculum was shaped by the individual self-examination of learning style preferences and strengths. Students' learning style preferences were assessed using the Productivity Environmental Preference Survey (Dunn, Dunn, \& Price, 1995). Weekly meetings consisted of group discussions on topics including identifying what went wrong, setting short and long-term goals, study skills, time management techniques, and stress management. Based on students' learning style preferences five main questions were posed: (a) Where should you study?, (b) With whom do you study?, (c) When do you study?, (d) How should you prepare for class and tests? and (e) How can you interact with your faculty to improve academic achievement? Activities were also included to increase student knowledge of careers in engineering and motivational strategies to shape short-term and long-term goals.

In addition to assigned readings and small group experiences, weekly journal entries were required to enhance and develop their self-awareness as learners. Students who had been on probation and succeeded in graduating and who were working as engineers were invited as guest speakers to discuss their academic experiences. The lively discussion covered a host of survival 
strategies proven successful to the guests. These were often reported by students as very helpful and highly motivating. A final paper was required which asked the students to synthesize what insights they gained about their learning styles and themselves as learners and what steps they had taken to be more academically successful.

All undergraduate freshman on probation were included in this evaluation report. Students were drawn from neighboring high schools in the New York metropolitan area and Long Island. They tended to be first in their families to attend college, were from middle to low income families and were ethnically diverse. They typically were included within the top $10 \%$ of their high school graduating classes and reported average combined SAT scores over 1000.

This evaluation report is based on data for 261 undergraduate students registered for the Academic Skills Seminar during the spring and fall semesters since Spring, 1995. To determine the relative success of this seminar, the following basic questions were posed: (1) Do students who complete the Seminar persist? (2) Do students who complete the Seminar return to and remain in good academic standing?, (3) Do students who complete the seminar demonstrate higher grade point averages? and (4) Has the Academic Skills Seminar impacted retention rates among first-year probation students? Please note that students completing the seminar during the Spring, 1995 would be entering their fourth year at the university so, consequently, no graduation data are available.

Do students who complete the Seminar persist at the university? Table 1 reports the registration status of all students who were registered for the Academic Skills Seminar during the two-year period beginning in Spring, 1995 as reported by the Registrar's Office June, 1997. 
Table 1: Registration Status of Students Registered for the Academic Skills Seminar Spring, 1995 through Spring, 1997

\begin{tabular}{|c|c|c|c|c|c|}
\hline & Passed Seminar & \multicolumn{2}{|c|}{ Failed Seminar } & \multicolumn{2}{|c|}{ Total } \\
\hline as of $6 / 97$ & $113 \quad(60.7 \%)$ & 28 & $(28.0 \%)$ & 141 & $(54.0 \%)$ \\
\hline Students Disqualified & $(14.5 \%)$ & 33 & $(44.0 \%)$ & 60 & $(22.9 \%)$ \\
\hline $\begin{array}{l}\text { Students Withdrawn } \\
\text { or Not Registered }\end{array}$ & $46 \quad(24.7 \%)$ & 14 & $(18.6 \%)$ & 60 & $(22.9 \%)$ \\
\hline Total & $186 \quad(100 \%)$ & 75 & $(100 \%)$ & 261 & $(100 \%)$ \\
\hline
\end{tabular}

A number of observations about student persistence can be made. Students who passed the Seminar persisted at a greater percentage rate $(60.7 \%$ vs. $28.0 \%)$ than those who failed the seminar. Of those freshmen placed on probation during this period, $54 \%$ persisted overall as compared to the $30 \%$ persistence rate reported by the Retention Committee earlier. Students who passed the Seminar were disqualified less frequently (14.5\% vs. $44.0 \%)$ than those who failed the Seminar. At a university of 1,500 undergraduates, the increase in retention is very important for the health of the institution. For the individual student, achieving success can make the difference in the career path they follow.

Students who passed the seminar left or withdrew at a higher percentage than those who failed. Perhaps the experiences and insights gained in the Seminar triggered these students to transfer to a less academically rigorous college or to switch to a less demanding academic major and return to being a "big fish in a little pond." Some chose to go to work full time.

Do students who complete the seminar return to, and remain in good standing? Table 2 reports the academic standing of the Seminar students as of June, 1997. Data are reported for each of the two campuses, as well as for the university. The academic standing descriptors 
indicate relative length of time on probation. Students in difficulty typically pass through a series of levels of probation. Academic standing is evaluated at the end of each academic semester. Maintaining good standing indicates that students have achieved a semester and cumulative grade point average of at least 2.0 for a year or more.

Table 2: Academic Standing of Students Registered in Academic Skills Seminar Spring, 1995 through Spring, 1997

\begin{tabular}{|c|c|c|c|}
\hline Academic Standing & New York City & Long Island Campus & Total \\
\hline Academic Warning & $\begin{array}{l}1(.5 \%) \\
1 \text { Pass* }\end{array}$ & $\begin{array}{l}2(2.7 \%) \\
2 \text { Pass }\end{array}$ & $\begin{array}{l}3(1.1 \%) \\
3 \text { Pass }\end{array}$ \\
\hline Initial Probation & $\begin{array}{l}17(8.9 \%) \\
12 \text { Pass } 5 \text { Fail ** }\end{array}$ & $\begin{array}{l}7(9.5 \%) \\
7 \text { Pass } \\
\end{array}$ & $\begin{array}{l}24(9.1 \%) \\
19 \text { Pass/ } 5 \text { Fail }\end{array}$ \\
\hline Continued Probation & $\begin{array}{l}51(26.8 \%) \\
38 \text { Pass/ } 13 \text { Fail }\end{array}$ & $\begin{array}{l}26(35.6 \%) \\
17 \text { Pass/9 Fail }\end{array}$ & $\begin{array}{l}77(29.2 \%) \\
55 \text { Pass/22 Fail }\end{array}$ \\
\hline Final Probation & $\begin{array}{l}35(18.4 \%) \\
27 \text { Pass/ } 8 \text { Fail }\end{array}$ & $\begin{array}{l}5(6.8 \%) \\
4 \text { Pass/ } 1 \text { Fail }\end{array}$ & $\begin{array}{l}38(14.4 \%) \\
31 \text { Pass/9 Fail }\end{array}$ \\
\hline Disqualified & $\begin{array}{l}47(24.7 \%) \\
20 \text { Pass/27 Fail }\end{array}$ & $\begin{array}{l}13(17.8 \%) \\
7 \text { Pass/ } 6 \text { Fail }\end{array}$ & $\begin{array}{l}60(22.8 \%) \\
27 \text { Pass/ } 33 \text { Fail }\end{array}$ \\
\hline $\begin{array}{l}\text { Dean' s List } \\
(\text { GPA > 3.4) }\end{array}$ & $\begin{array}{l}3(1.5 \%) \\
3 \text { Pass } \\
\end{array}$ & 0 & $\begin{array}{l}3(1.1 \%) \\
3 \text { Pass }\end{array}$ \\
\hline $\begin{array}{l}\text { Returned to Good } \\
\text { Academic Standing }\end{array}$ & $\begin{array}{l}19(10.0 \%) \\
15 \text { Pass/4 Fail }\end{array}$ & $\begin{array}{l}14(19.1 \%) \\
13 \text { Pass/ } 1 \text { Fail }\end{array}$ & $\begin{array}{l}33(12.5 \%) \\
28 \text { Pass/ } 5 \text { Fail }\end{array}$ \\
\hline $\begin{array}{c}\text { Maintained Good } \\
\text { Standing } \\
\end{array}$ & $\begin{array}{l}17(8.9 \%) \\
16 \text { Pass/ } 1 \text { Fail }\end{array}$ & $\begin{array}{l}6(8.2 \%) \\
6 \text { Pass } \\
\end{array}$ & $\begin{array}{l}23(8.7 \%) \\
22 \text { Pass/ 1 Fail }\end{array}$ \\
\hline Total & $\begin{array}{l}190(100 \%) \\
132 \text { Pass/ 58 Fail }\end{array}$ & $\begin{array}{l}73(100 \%) \\
56 \text { Pass/ } 17 \text { Fail }\end{array}$ & $\begin{array}{l}263(100 \%) \\
188 \text { Pass/ } 75 \text { Fail }\end{array}$ \\
\hline
\end{tabular}

Of those registered for Seminar, 22.3\% were in good academic standing, while 54.9\% remained on probation. Those remaining on probation might require more than one semester to 
sufficiently raise the grade point average over the 2.0 level. Those students disqualified (22.8\%) earned grade point averages substantially below minimal levels required by the university.

In all academic standing categories, the number of students passing the seminar was higher than number failing, except in the category of disqualification. Those whose performance was very poor also tended to be those who did not complete the basic requirements of the Seminar to earn a passing grade.

Do students who complete the seminar demonstrate higher grade point averages than students who do not complete the Seminar? Table 3 reports the mean cumulative grade point averages of students who either passed or failed the Seminar.

Table 3: Mean Cumulative Grade Point Average (GPA) of Students Who Passed or Failed Academic Skills Seminar

Spring 1995 to Spring 1997

\begin{tabular}{|l|l|l|l|l|}
\multicolumn{2}{c}{ New York City Campus } & \multicolumn{2}{c|}{ Long Island Campus } \\
\hline & Passed Seminar & Failed Seminar & Passed Seminar & Failed Seminar \\
\hline $\begin{array}{l}\text { Mean Cumulative } \\
\text { Grade Point Average } \\
\text { (GPA) }\end{array}$ & 1.88 & 1.30 & 1.87 & 1.38 \\
\hline Median GPA & 1.90 & 1.36 & 1.96 & 1.45 \\
\hline Range & 3.04 & 2.36 & 2.60 & 2.72 \\
\hline Minimum & .39 & 0.00 & .16 & 0.00 \\
\hline Maximum & 3.43 & 2.36 & 2.76 & 2.72 \\
\hline Count & 131 & 60 & 53 & 18 \\
\hline
\end{tabular}

Table 4 indicates the results of a t-test to determine if the difference between the mean GPA of students who passed the seminar was significantly different than the mean GPA of students who failed the seminar. 
Table 4: $\mathrm{t}$ - Test: Two Sample Assuming Unequal Variances*

\begin{tabular}{|l|l|l|}
\hline & Passed Seminar & Failed Seminar \\
\hline Mean & 1.87 & 1.33 \\
\hline Variance & 0.26 & 0.47 \\
\hline Observations & 184 & 76 \\
\hline df & 111 & \\
\hline t Stat & $6.10 * *$ & $* * \mathrm{p}<.05$ \\
\hline
\end{tabular}

* Results of the F-test revealed a significant difference between the reported variance of the groups. Therefore, the t-test for unequal variances was employed.

Students who passed the Academic Skills Seminar achieved a significantly higher cumulative grade point average (.5 on 4.0 scale) than students who failed the seminar.

Has the Academic Skills Seminar impacted retention rates among first-time probation freshmen? Table 5 reports the comparative academic status of freshmen placed on probation during the at the end of the Fall, 1992, to Spring, 1994 semesters and the rates of the similar population after the Seminar was implemented.

Table 5: Comparative Persistence Rates of Freshmen on Probation Before and After the Seminar Intervention Was Institutionalized

\begin{tabular}{|l|l|l|l|}
\hline & $\begin{array}{l}\text { Spring 1993 } \\
\text { Freshmen on } \\
\text { Probation, } \\
1992-1994 \\
\text { Persistence Rate }\end{array}$ & $\begin{array}{l}\text { Spring 1995 } \\
\text { Freshmen on } \\
\text { Probation, } \\
1995-1997 \\
\text { Persistence Rate }\end{array}$ & $\begin{array}{l}\text { Spring 1995 } \\
\text { Freshmen on } \\
\text { Probation Who } \\
\text { Passed Seminar } \\
1995-1997 \\
\text { Persistence Rate }\end{array}$ \\
\hline $\begin{array}{l}\text { First-Year Probation Students } \\
\text { Who Persisted }\end{array}$ & $20(23.7 \%)$ & $26(31.3 \%)$ & $25(35.2 \%)$ \\
\hline Disqualified & $12(14.6 \%)$ & $23(27.7 \%)$ & $15(21.1 \%)$ \\
\hline Withdrew & $50(60.9 \%)$ & $34(40.9 \%)$ & $31(43.6 \%)$ \\
\hline
\end{tabular}




\begin{tabular}{|l|l|l|l|}
\hline Total & $82(100 \%)$ & $83(100 \%)$ & $71(100 \%)$ \\
\hline
\end{tabular}

The persistence rate among freshmen on probation increased by $8.4 \%$ after the introduction of the Academic Skills Seminar. Further, the persistence rate for freshmen on probation who passed the Seminar increased by $11.5 \%$ as compared to the two years prior to its inception. While there was a decrease ( $60.9 \%$ to $40.9 \%$ ) in the percentage of those who withdrew, there was an increase in those who were disqualified (14.6\% to $27.7 \%$ ). Given that the policy and practice for decisions on disqualification were unchanged during this time, there could be several possible reasons for these results. It may be that the increased number of hours students work may account for this pattern. Students on probation who know they should be working fewer hours are not always in a financial position to cut back. They concurrently are unwilling to enroll part-time because of the financial aid reductions. It may also be that the seminar provides increased motivation for some students to remain in school without the determination to commit to a rigorous academic schedule for the whole semester. Some simply give up before finals.

Students are required to write a final paper reflecting on their learning strengths and defining what they need to do to be academically successful at the university. These final papers were placed on file and provided insights into the qualitative and human side of academic life at the university. As described by the Big Fish, Little Pond (BFLP) effect, students consistently describe their overwhelming sense of feeling "stupid" after finding out that they failed. Many had never failed a course before, let alone failed the semester. They believed that their peers were brilliant and that they were the only freshman failing. Often, as the first in their families to attend college, the agony of disappointing their parents was very painful. Many did not tell their families how poorly they were doing in school.

Upon walking into Seminar the first day of classes and finding they were among a 
classroom full of freshmen who failed, they reported feeling much better about themselves as students. Hearing other students who failed speak about their eventual success was reported as giving them hope and providing the motivation to tackle a new semester. They reported that the weekly discussions helped them achieve their short-term goals for the semester. Some found the weekly meetings helpful reminders that they were on probation and provided the push to keep them on track academically.

Students also reported that becoming more aware of their learning style strengths and reconsidering how they studied, where they studied, with whom they studied were valuable strategies. In high school they were the Big Fish, but were not sufficiently challenged to have to develop a rigorous work ethic. In college they became the Small Fish attempting for the first time to figure out how to study effectively. The important point to help them understand was the difference between failing because of a lack of aptitude and ability and failing because of poor study behaviors. Behaviors can change. That message made a big difference in how they viewed themselves as learners. Experiencing academic failure because of inappropriate study skill behaviors is a very different explanation than failure because of insufficient aptitude.

In summary, the data suggest that the Academic Skills Seminar should be continued as an intrusive freshman program. Students who complete the seminar earn grade point averages significantly higher than those students who fail the course. Further, probation students were retained at a higher percentage rate after the Academic Skills Seminar was introduced as compared with a control group.

\section{References}

Astin, A. W. (1993). What Matters in College: Four Critical Years Revisited. San Francisco, CA: JosseyBass Publishers.

Buell, B. G., \& Buell, N. A. (1987). Perceptual modality preference as a variable in the effectiveness of 
continuing education for professionals. Dissertation Abstracts International, 48, 872A.

Brown, S. D., Lent, R. W., \& Larkin, K. C. (1989). "Self-efficacy as a moderator of scholastic aptitudeacademic performance relationships." Journal of Vocational Behavior, 35, 64-75.

Bruno, J. (1988). An experimental investigation of the relationships between and among hemispheric processing, learning style preferences, instructional strategies, academic achievement, and attitudes of developmental mathematics students in an urban technical college. (Doctoral dissertation, St. John's University, 1988).

Carver, D. S., \& Smart, D.W. (1985). "The effects of a career and self-exploration course for undecided freshmen". Journal of College Student Personnel, 26, 37-43.

Clay, J. E. (1984). A correlational analysis of the learning characteristics of highly achieving and poorly achieving freshmen at $A \& M$ university as revealed through performance on standardized tests. Unpublished doctoral dissertation, A \& M University, Normal, Alabama.

Coleman, H. L., \& Freedman, A. L. (1996). "Effects of a structured group intervention on the achievement of academically at-risk undergraduates". Journal of College Student Development, 37, 631-636.

Cook, L. (1989). Relationships among learning style awareness, academic achievement, and locus of control among community college students. Dissertation Abstracts International, 49, 217A.

Dunn, R., Deckinger, L., Withers, P., \& Katzenstein, H. (1990). "Should college students be taught how to do homework?" Illinois Research and Development Journal, 26(2), 96-113.

Dunn, R., Dunn, K., \& Price, G. (1995) Productivity Environmental Preference Survey, Lawrence, KS: Price Systems, Inc.

Hacket, G., Casas, J. M., Betz, N. E., \& Rocha-Singh, I. A. (1992). "Gender, ethnicity, and social cognitive factors predicting the academic achievement of students in engineering", Journal of Counseling Psychology, 39(4) 527-538.

House, J. D. (1993). “The relationship between academic self-concept and school withdrawal." Journal of Social Psychology, 133(1), 125-127.

Lenehan, M. C., Dunn, R., Ingham, J. M., Signer, B., Murray, J. B., (1994). "Effects of learning-style intervention on college students' achievement, anxiety, anger, and curiosity." Journal of College Student Development, 35, 461-466.

Lipsky, S. A., \& Ender, S. C. (1990). "Impact of a study skills course on probationary students' academic performance". Journal of the Freshman Year Experience, 2, 7-15.

Marsh, H. W. (1984)a. "Self-concept: The application of a frame of reference model to explain paradoxical results:. Australian Journal of Education, 28, 165-181.

Marsh, H. W. (1984)b. "Self-concept, social comparison and ability grouping: A reply to Kulik and Kulik." American Educational Research Journal, 21, 799-806.

Marsh, H. W. (1991). "The failure of high ability high schools to deliver academic benefits: The importance of academic self-concept and educational aspirations." American Educational Research Journal, 
$28,445-480$.

Marsh, H. W., \& Craven, R. (1997). "Academic self-concept: Beyond the dustbowl”, Chapter 6 in , Handbook of Classroom Assessment: Learning, Achievement, and Adjustment, ed. G. D. Phye, New York: Academic Press.

Napolitano, R., (1986). An experimental investigation of the relationships among achievement, attitude scores, and traditionally, marginally, and underprepared college students enrolled in a introductory psychology course when they are matched and mismatched with their learning style preferences for the element of structure. Dissertation Abstracts International, 47, 435A.

Nelson, B., Dunn, R., Griggs, S. A., Primavera, L., Fitzpatrick, M., \& Miller, R. (1993). "Effects of learning style intervention on college students' retention and achievement." Journal of College Student Development, 34,364-369.

Newton, F. B. (1990). "Academic support seminars: A program to assist students experiencing academic difficulty". Journal of College Student Development, 31, 183-186.

Quilter, S. M. (1995). “Academic self-concept and the first-year college student: A snapshot". Journal of the Freshman Year Experience, 7(1), 39-52.

Simmons, G., Wallins, J., \& George, A.. (1995). "The effects of a freshman seminar on at-risk under-, overand low achievers". The Journal of the National Academic Advising Association, 15(1), 8-14.

Tinto, V. (1993). Leaving College: Rethinking the causes and cures of student attrition. Chicago: University of Chicago Press.

Wilhite, S. C. (1990). "Self-efficacy, locus of control, self-assessment of memory ability, and study activities as predictors of college course achievement". Journal of Educational Psychology, 82(4), 696-700.

JOANNE INGHAM, Ed..D is the Director of Institutional Assessment \& Retention at Polytechnic University, Brooklyn, NY.

DR. WILLIAM R. MCSHANE, Ph.D., P.E. is the Vice President and Dean of Engineering and Applied Sciences at Polytechnic University, Brooklyn, New York and also serves as a member of the faculty in Mechanical Engineering. 